\title{
Pengaruh Kompetensi, Sistem Pengendalian Internal, Kepatuhan Pajak, Dan Partisipasi Masyarakat Terhadap Akuntabilitas Pengelolaan Alokasi Dana Desa
}

\author{
Muhamad Rifa'i, Jubertus dan Riski Aprilia Dwi Susanti \\ Universitas Tribhuwana Tungga Dewi Malang, Indonesia \\ Email corresponding author: rifaiunitri@gmail.com
}

\begin{abstract}
ABSTRAK
Desa sebagai wilayah terkecil dalam struktur pemerintahan yang menjadi salah satu fokus utama pemerintah dalam pembangunan negara, harus mengalami peningkatan untuk mencapai masyarakat yang sejahtera dan bebas dari kemiskinan. Hal ini didukung dengan pengelolaan keuangan desa yang baik. Namun dalam praktiknya, banyak terjadi kasus penyelewengan keuangan desa oleh pihak-pihak yang tidak bertanggung jawab sehingga menimbulkan kerugian yang besar. Hasil penelitian menjukkan bahwa kompetensi perangkat desa, sistem pengendalian internal, kepatuhan pajak bendaharawan desa, dan partisipasi masyarakat berpengaruh signifikan terhadap akuntabilitas pengeloaan alokasi dana desa.
\end{abstract}

Kata Kunci : Kompetensi, Pengendalian Internal, Kepatuhan Pajak, Partisipasi Masyarakat, Akuntabilitas, Alokasi Dana Desa.

\section{ABSTRACT}

The village as the smallest area in the government structure which is one of the main focuses of the government in state development, must experience improvement to achieve a prosperous society and free from poverty. This is supported by good village financial management. However, in practice, there are many cases of misappropriation of village finances by irresponsible parties, causing huge losses. The results of the study show that the competence of village officials, internal control systems, village treasurer tax compliance, and community participation have a significant effect on accountability for managing village fund allocations.

Keyword : Competence, Internal Control, Tax Compliance, Community Participation, Accountability, Village Fund Allocation.

\section{PENDAHULUAN}

Era reformasi adalah era dimana pemerintah harus terbuka terhadap segala hal termasuk di dalamnya pemerintah desa. Pemerintah desa harus siap dan mampu menyampaikan segala informasi secara terbuka tentang berbagai kebijakan, terutama menyangkut kebijakan publik seperti rencana pembangunan yang menggunakan dana masyarakat melalui APBDes. Seluruh proses penyelenggaraan pemerintah desa, mulai dari perencanaan, alokasi anggaran, pelaksanaan kegiatan, monitoring, evaluasi, dan pelaporan harus melibatkan masyarakat (Yansen, 2014).

Anggaran disusun berdasarkan jadwal yang dibuat dengan cermat berdasarkan perkiraan untuk tahun mendatang. Ada dua prinsip penganggaran dan sistem penganggaran desa, yakni: Pertama, anggaran untuk satu tahun. Kedua, anggaran berimbang, yaitu anggaran pada akhir tahun anggaran berimbang. Tercapainya transparansi dan akuntabilitas di tingkat desa merupakan pintu masuk bagi pemerintah desa untuk memberikan informasi kepada masyarakat. Baik yang berkaitan dengan pengelolaan keuangan desa maupun informasi yang berkaitan dengan kebijakan pemerintah desa. Hal 
ini dikarenakan masyarakat mempunyai hak untuk mendapatkan informasi dalam melakukan pengawasan terhadap kinerja pemerintah desa. Dana desa adalah dana yang berasal dari Anggaran Pendapatan dan Belanja Negara (APBN) yang diperuntukan bagi Desa dan Desa Adat, yang ditransfer melalui Anggaran Pendapatan dan Belanja Daerah (APBD) kabupaten/kota dan untuk membiayai penyelenggaraan, pembangunan pemerintahan, dan penguatan masyarakatan.

Untuk mencatat keuangan dana desa maka diperlukan tangggung jawab atau Akuntablitas adalah suatu bentuk pertanggungjawaban seseorang (direktur, pejabat atau pelaksana) atau suatu organisasi pada pihak-pihak yang memiliki hak atau wewenang untuk memberikan informasi atas kinerja atau tindakan dalam pemenuhan misi dan tujuan organisasi dalam bentuk laporan yang diminta secara berkala. Menurut Mursyidi (2013), akuntabilitas bertanggung jawab untuk mengelola sumber daya dan melaksanakan kebijakan yang dipercayakan kepada unit pelaporan untuk mencapai tujuan yang telah ditetapkan secara teratur.

Dana desa adalah dana yang berasal dari anggaran pendapatan dan belanja negara untuk desa yang ditransfer melalui anggaran pendapatan dan belanja daerah Kabupaten/Kota untuk mendanai penyelenggaraan pemerintahan, pelaksanaan pembangunan, pembinaan dan pemberdayaan masyarakat. Dana desa memegang peranan penting dalam meningkatkan perekonomian masyarakat pedesaan. Dengan penggunaan dan alokasi yang efektif dan efisien. Pengelolaan keuangan desa berdasarkan Permendagri No.113 Tahun 2014 tentang pengelolaan keuangan desa adalah keseluruhan proses kegiatan dimulai dari perencanaan, pelaksanaan, penatausahaan, pelaporan, pertanggungjawaban, serta pembinaan dan pengawasan keuangan desa. Keuangan desa dikelola berdasarkan asas-asas transparan, akuntabel, partisipatif serta dilakukan dengan tertib dan disiplin anggaran. Menurut Permendagri No 113 Tahun 2014 tentang pengelolaan keuangan desa adalah penatausahaan hanya terdiri dari buku-buku dengan dilengkapi bukti-bukti transaksi. Selain itu bendahara dapat membuat laporan keuangan berupa neraca. Neraca menggambarkan keadaan kekayaan, keuangan, dan kekayaan desa dalam satu periode.

UU Desa menegaskan bahwa desa adalah kesatuan masyarakat hukum yang memiliki batas wilayah, berwenang untuk mengatur dan mengurus urusan pemerintahan, kepentingan masyarakat setempat berdasarkan prakarsa masyarakat, hak asal usul dan hak tradisional yang diakui serta dihormati menjadi sistem pemerintahan Negara Kesatuan Republik Indonesia (UU No. 6 Tahun 2014 Pasal 1 ayat 1$)$.

Dari sini dapat disimpulkan bahwa desa adalah suatu badan hukum dengan batas-batas wilayah yang berwenang untuk mengatur kepentingan masyarakat setempat dan urusan pemerintahan berdasarkan prakarsa, asal usul dan adat istiadat masyarakat setempat, serta hak dan kewajiban masyarakat setempat, hak tradisional menyelenggarakannya diakui dan dihormati dalam sistem pemerintahan Negara Kesatuan Republik Indonesia. Pelaksanaan otonomi desa akan menjadi kekuatan bagi pemerintah desa untuk mengatur anggarannya sendiri serta menambah beban tanggung jawab dan tugas desa, namun demikian penyelenggaraannya harus tetap dapat dipertanggung jawabkan kepada pemerintah.

Dalam hal pemerintahan desa, masyarakat desa sebagai principal menyerahkan kewengan pengelolaan keuangan desa kepada pemerintah desa sebagai agen, dan menuntut agen memiliki kompetensi sehingga dapat melaksanakan pengelolaan dana desa secara akuntabel. Gayatri et al. (2019) yang menganalisis faktor-faktor yang mempengaruhi Akuntabilitas Pengelolaan Dana Desa mengungkapkan bahwa kompetensi perangkat desa berpengaruh secara positif dan signifikan terhadap akuntabilitas pengelolaan dana desa.

Selanjutnya dalam pengelolaan dana desa yang tidak sedikit Pemerintah desa sebagai agen membutuhkan alat bantu berupa sistem informasi yang dapat mempermudah kinerja dalam pengelolaan dana desa. Sistem informasi dapat diartikan sebagai suatu pengorganisasian peralatan untuk mengumpulkan, menginput, memproses, menyimpan, mengatur, mengontrol dan melaporkan informasi untuk pencapaian tujuan organisasi. Untuk itu Pemerintah melalui 
BPKP dapat membantu pengelolaan dana desa yaitu sistem pengendalian internal. Juardi et al. (2018) mengungkapkan bahwa pemanfaatan sistem pengendalian internal dapat meningkatkan akuntabilitas pengelolaan keuangan desa.

Adapun peran pajak yang merupakan sumber penerimaan terbesar negara, menuntut pemerintah melalui Dirjen Pajak berupaya untuk mengintensifkan penerimaan pajak salah satunya dengan meningkatkan kepatuhan pajak melalui sosialisasi dan pelatihan. Adapun kepatuhan pajak dapat diartikan sebagai kesadaran wajib pajak dalam melaksanakan kewajiban perpajakannya sesuai peraturan perundang- undangan perpajakan, yang meliputi wajib pajak membayar pajak dengan tepat waktu, tepat jumlah dan tepat tanggungan pajak (Subarkah dan Dewi, 2017). Dalam pengelolaan dana desa, bendaharawan desa merupakan pelaksana pemotongan, penyetoran dan pelaporan pajak. Pengaruh kepatuhan Bendaharawan Desa sebagai variable independent atau variabel yang berpengaruh terhadap akuntabilitas dana desa menjadi kebaruan dari penelitian ini. Penelitian sebelumnya lebih kepada kepatuhan pajak sebagai variable dependent atau dipengaruhi, diantaranya Subandhi dan Fadhil (2018) yang yang menganalisis faktor- faktor yang mempengaruhi kepatuhan wajib pajak. Kepatuhan pajak bendaharawan desa berdasar kepada stewardship theory yang merupakan salah satu cabang psikologi dan sosiologi dan didesain untuk menguji kondisi dimana eksekutif sebagai pengelola yang termotivasi untuk melakukan yang terbaik terhadap kepentingan utama organisasi.

Partisipasi masyarakat dalam penelitian ini adalah pendapat responden atas keterlibatan dan atau keikutsertaan masyarakat secara sadar dalam proses pembangunan dalam rangka mencapai suatu kondisi yang lebih baik dari sebelumnya. Berdasarkan agency theory dimana masyarakat sebagai principal memberikan kepercayaan kepada pemerintah sebagai agen dalam pengelolaan keuangan desa. Widarnawati (2018) menyatakan bahwa akuntabilitas pengelolaan keuangan yang baik sangat ditentukan oleh partisipasi masyarakat yang tinggi.

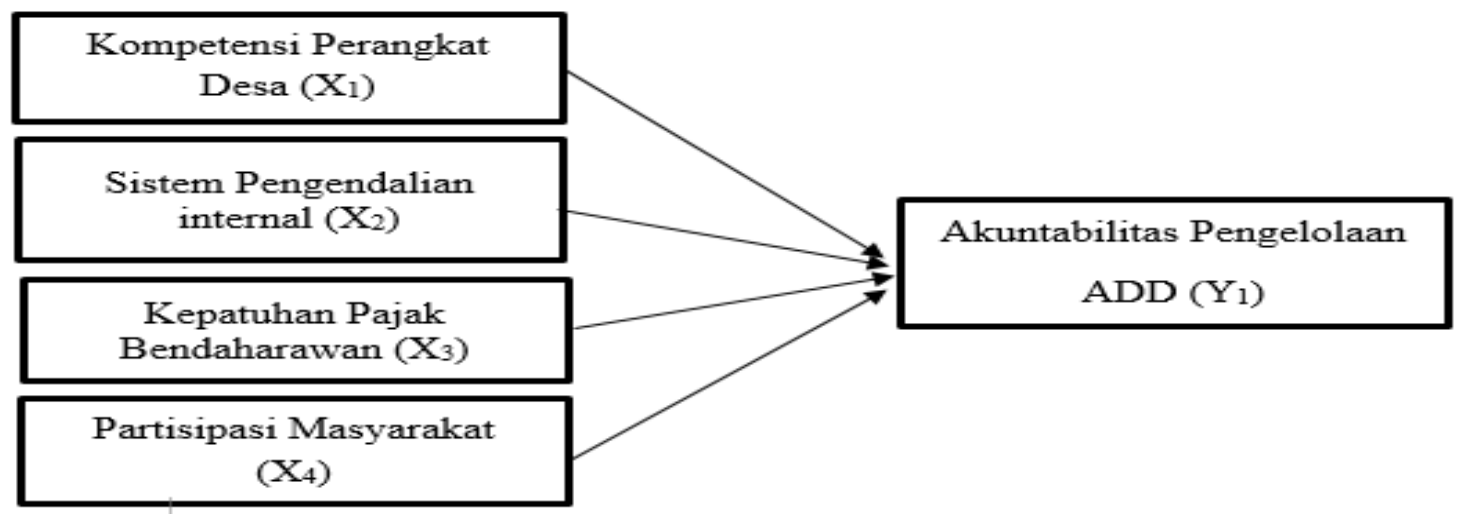

Gambar 1. Kerangka Pikir Penelitian

Hipotesis Peenelitian:

H1. Kompetensi perangkat desa berpengaruh positif terhadap terwujudnya akuntabilitas pengelolaan dana desa.

$\mathrm{H}_{2 .}$.Sistem pengendalian internal berpengaruh positif terhadap terwujudnya akuntabilitas pengelolaan dana desa. 
H3. Kepatuhan Pajak Bendaharawan Desa memiliki pengaruh yang positif terhadap terwujudnya akuntabilitas pengelolaan dana desa

H4. Partisipasi masyarakat memiliki pengaruh postif terhadap terwujudnya akuntabilitas pengelolaan dana desa.

\section{METODE PENELITIAN}

Penelitian ini menggunakan pendekatan kuantitatif, jenis penelitian ini merupakan penelitian kausalitas yang bertujuan untuk menjelaskan hubungan antar variabel. Pertimbangan jenis tersebut adalah untuk menganalisis hubungan kausalitas (causality relationship) antara faktorfaktor yang mempengaruhi akuntabilitas pengelolaan alokasi dana desa. Adapun variabel independen pada penelitian ini adalah kompetensi perangkat desa $\left(\mathrm{X}_{1}\right)$, sistem pengendalian internal $\left(\mathrm{X}_{2}\right)$, kepatuhan pajak bendaharawan desa $\left(\mathrm{X}_{3}\right)$ dan partisipasi masyarakat $\left(\mathrm{X}_{4}\right)$ sedangkan variabel terikat atau dependen adalah Akuntabilitas pengelolaan Alokasi dana desa (Y). Lokasi penelitian dilakukan di desa Tegalweru kecamatan Dau, kabupaten Malang provinsi jawa Timur. Populasi dalam penelitian ini adalah 3.570 jumlah penduduk yang didalamnya termasuk perangkat desa. Teknik penentuan sampel dilakukan dengan purposive random sampling dengan jumlah sampel yang diambil adalah 98 responden yang jumlahnya ditentukan berdasarkan rumus Slovin. Sumber data yang digunakan adalah data primer dengan cara memberikan kuesioner kepada respondenn dan data skunder dengan cara mengambil data-data pendukung yang relevan dengan penelitian ini. Untuk menjamin kualitas data primer maka dalam penelitian ini dilakukan uji validitas dan reliabilitas terhadap instrumen yang digunakan. Analisis data yang digunakan adalah analisis Regresi linier berganda yang melakukan uji asumsi klasik tertebih dahulu terhadap data yang diperoleh sebelum dilakukan pengujian data hasil penelitian.

\section{HASIL DAN PEMBAHASAN}

Penelitian ini dilakukan di Desa Tegalweru Kabupaten Malang. Tegalweru merupakan salah satu desa di Kecamatan Dau, Kabupaten Malang, Provinsi Jawa Timur. Jarak tempuh desa Tegalweru dengan pusat Kabupaten Malang adalah $15 \mathrm{~km}$ yang dapat ditempuh dalam waktu sekitar 45 menit, sedangkan jarak tempuh dengan pusat kecamatan Dau adalah $5 \mathrm{~km}$ yang dapat ditempuh sekitar 15 menit. Batas wilayah Tegalweru disebelah selatan berbatasan dengan Desa Petungsewu/Karangwidoro, disebelah utara berbatasan dengan Desa Gadingkulon, disebelah timu rberbatasan dengan Desa Merjosari dan disebelah barat berbatasan dengan Desa Selorejo. Uji validitas dilakukan dalam penelitian ini untuk mengukur sah atau valid suatu kuesioner, adapun data yang dinyatakan valid apabila nilai korelasi yaitu $\left(\mathrm{r}_{\text {hiung }}\right)>\left(\mathrm{r}_{\text {tabel }}\right)$. Berikut disajikan hasil pengujian instrumen uji vailiditas:

Tabel 1. Hasil Uji Validitas

\begin{tabular}{cccccccc}
\hline \multirow{2}{*}{ Var/No } & \multicolumn{5}{c}{ r hitung } & \multirow{2}{*}{ r tabel } & \multirow{2}{*}{ Kesimpulan } \\
\cline { 2 - 5 } & $\mathrm{X}_{1}$ & $\mathrm{X}_{2}$ & $\mathrm{X}_{3}$ & $\mathrm{X}_{4}$ & $\mathrm{Y}$ & & Valid \\
\hline 1 & 0,814 & 0,798 & 0,815 & 0,757 & 0,709 & & Valid \\
3 & 0,733 & 0,815 & 0,698 & 0,810 & 0,725 & 0,195 & Valid \\
\hline
\end{tabular}

Sumber : Data primer (diolah), 2021

Berdasarkan tabel 1 dapat diketahui bahwa instrumen yang digunakan dalam penelitian yaitu variabel kompetensi perangkat desa $\left(\mathrm{X}_{1}\right)$ terdiri dari 3 pernyataan, variabel sistem pengendalian internal $\left(X_{2}\right)$ terdiri dari 2 pernyataan, variabel kepatuhan pajak bendaharawan desa $\left(X_{3}\right)$ terdiri dari 3 pernyataan, variabel partisipasi masyarakat $\left(\mathrm{X}_{4}\right)$ terdiri dari 2 pernyataan dan variabel 
akuntabilitas pengeloaan alokasi dana desa (Y) juga terdiri dari 3 pernyataan, dari semua pernyataan data dinyatakan valid karena nilai ( $\left.\mathrm{r}_{\text {hitung }}\right)>\left(\mathrm{r}_{\text {tabel }}\right)$ sebesar 0,195 .

Uji Reliabilitas dilakukan untuk mengukur tingkat kepercayaan atau keabsahan instrumen yang dipergunakan, dalam pengujian reliabilitas ini menggunakan koefisiensi alpha cronbach untuk mengetahui apakah hasil pengukuran data yang diperoleh memenuhi syarat reliabilitas atau tidak. Adapun kriteria reliabilitas dengan menggunakan alpha cronbach adalah apabila hasil korelasi alpha lebih besar dari 0,6 maka instrumen dikatakan reliabel dan sebaliknya. Hasil pengujian reliabilitas diasajikan pada tabel berikut:

Tabel 2 Hasil Uji Reliabilitas

\begin{tabular}{cccc}
\hline Variabel & Alpha Cronbach & Alpha & Keterangan \\
\hline$\left(\mathrm{X}_{1}\right)$ & 0,810 & & Reliabel \\
$\left(\mathrm{X}_{2}\right)$ & 0,837 & & Reliabel \\
$\left(\mathrm{X}_{3}\right)$ & 0,812 & 0,6 & Reliabel \\
$\left(\mathrm{X}_{4}\right)$ & 0,820 & & Reliabel \\
$(\mathrm{Y})$ & 0,788 & & Reliabel \\
\hline
\end{tabular}

Sumber: Data primer (diolah), 2021

Berdasarkan tabel 2 dapat disimpulkan bahwa semua item pernyataan dari variabel kompetensi perangkat desa $\left(\mathrm{X}_{1}\right)$, variabel sistem pengendalian internal $\left(\mathrm{X}_{2}\right)$, variabel kepatuhan pajak bendaharawan desa $\left(\mathrm{X}_{3}\right)$, variabel partisipasi masyarakat $\left(\mathrm{X}_{4}\right)$ dan variabel akuntabilitas pengeloaan alokasi dana desa (Y) mempunyai koefisien Alpha lebih besar dari 0,6 dengan demikian item pernyataan untuk semua variabel tersebut dinyatakan reliabel. Analisis regresi linear berganda digunakan untuk mengetahui besarnya pengaruh dari faktor-faktor akuntabilitas pengelolaan alokasi dana desa di Desa Tegalweru Kabupaten Malang. Hasil uji Regresi Linear Berganda diketahui pada tabel berikut.

Tabel 3. Hasil Uji Regresi Linier Berganda

\begin{tabular}{|c|c|c|c|c|c|c|}
\hline \multirow[b]{2}{*}{ Mode } & & \multicolumn{2}{|c|}{$\begin{array}{l}\text { Unstandardized } \\
\text { Coefficients }\end{array}$} & \multicolumn{2}{|l|}{$\begin{array}{l}\text { Standardized } \\
\text { Coefficients } \\
\end{array}$} & \multirow[b]{2}{*}{ Sig. } \\
\hline & & $\mathrm{B}$ & Std. Error & Beta & $\mathrm{t}$ & \\
\hline \multirow[t]{5}{*}{1} & $\begin{array}{l}\text { (Constant } \\
\text { ) }\end{array}$ & 5.719 & 1.816 & & 3.150 & .002 \\
\hline & $\mathrm{X} 1$ & .574 & .180 & .571 & 3.188 & .002 \\
\hline & $\mathrm{X} 2$ & .617 & .174 & .662 & 3.546 & .000 \\
\hline & $\mathrm{X} 3$ & .716 & .119 & .730 & 6.016 & .000 \\
\hline & $\mathrm{X} 4$ & .794 & .105 & .736 & 7.562 & .000 \\
\hline
\end{tabular}

a. Dependent Variable: Y1

Sumber: data Primer (diolah), 2021

Berdasarkan tabel 3 dapat dibuat persamaan regresi untuk mengukur tingkat pengaruh variabel kompetensi perangkat desa $\left(\mathrm{X}_{1}\right)$, variabel sistem pengendalian internal $\left(\mathrm{X}_{2}\right)$, variabel kepatuhan pajak bendaharawan desa $\left(\mathrm{X}_{3}\right)$ dan variabel partisipasi masyarakat $\left(\mathrm{X}_{4}\right)$ terhadap variabel akuntabilitas pengeloaan alokasi dana desa $(\mathrm{Y})$ menggunakan persamaan regresi sebagai berikut: $Y=a+b_{1} X_{1}+b_{2} X_{2}+b_{3} X_{3}+b_{4} X_{4}+e . Y=5,719+0,574 X_{1}+0,617 X_{2}+0,716 X_{3}+0,794 X_{4}$ + e. Berdasarkan persamaan regresi dapat diartikan bahwa, untuk nilai variabel akuntabilitas pengeloaan alokasi dana desa sebesar nilai konstanta yaitu 5,719. Berdasarkan uji regresi linear berganda diketahui bahwa partisipasi masyarakat berpengaruh dominan terhadap akuntabilitas 
pengeloaan alokasi dana desa di Desa Tegalweru Kabupaten Malang dengan nilai koefisien regresi sebesar 0,794. Jika nilai variabel $\mathrm{X}_{1}, \mathrm{X}_{2}, \mathrm{X}_{3}$ dan $\mathrm{X}_{4}$ bertambah sebesar 2,701, maka nilai pengaruh total sebesar 8,420, dengan demikian makna nilai regresi dari masing-masing variabel sebagai berikut:

$\mathrm{Y}=$ variabel akuntabilitas pengeloaan alokasi dana desa yang merupakan variabel terikat yang nilainya akan diprediksi oleh variabel kompetensi perangkat desa $\left(\mathrm{X}_{1}\right)$, variabel sistem pengendalian internal $\left(\mathrm{X}_{2}\right)$, variabel kepatuhan pajak bendaharawan desa $\left(\mathrm{X}_{3}\right)$ dan variabel partisipasi masyarakat $\left(\mathrm{X}_{4}\right)$

$\mathrm{X}_{1}=$ koefisien regresi $\left(\mathrm{X}_{1}\right)$ sebesar 0,574 dengan tanda menyatakan bahwa variabel kompetensi perangkat desa $\left(\mathrm{X}_{1}\right)$ mempunyai pengaruh positif terhadap variabel akuntabilitas pengeloaan alokasi dana desa (Y), hal ini berarti variabel kompetensi perangkat desa mendukung peningkatan akuntabilitas pengeloaan alokasi dana desa di Desa Tegalweru Kabupaten Malang.

$\mathrm{X}_{2}=$ koefisien regresi $\left(\mathrm{X}_{2}\right)$ sebesar 0,617 dengan tanda menyatakan bahwa variabel sistem pengendalian internal $\left(\mathrm{X}_{2}\right)$ mempunyai pengaruh positif terhadap variabel akuntabilitas pengeloaan alokasi dana desa (Y), hal ini berarti variabel sistem pengendalian internal mendukung peningkatan akuntabilitas pengeloaan alokasi dana desa di Desa Tegalweru Kabupaten Malang.

$\mathrm{X}_{3}=$ koefisien regresi $\left(\mathrm{X}_{3}\right)$ sebesar 0,716 dengan tanda menyatakan bahwa variabel kepatuhan pajak bendaharawan desa $\left(\mathrm{X}_{3}\right)$ mempunyai pengaruh positif terhadap variabel akuntabilitas pengeloaan alokasi dana desa (Y), hal ini berarti variabel kepatuhan pajak bendaharawan desa mendukung peningkatan akuntabilitas pengeloaan alokasi dana desa di Desa Tegalweru Kabupaten Malang.

$\mathrm{X}_{4}=$ koefisien regresi $\left(\mathrm{X}_{4}\right)$ sebesar 0,794 dengan tanda menyatakan bahwa dan variabel partisipasi masyarakat $\left(\mathrm{X}_{4}\right)$ mempunyai pengaruh positif terhadap variabel akuntabilitas pengeloaan alokasi dana desa (Y), hal ini berarti variabel partisipasi masyarakat mendukung peningkatan akuntabilitas pengeloaan alokasi dana desa di Desa Tegalweru Kabupaten Malang.

Uji t dilakukan untuk mengetahui besarnya pengaruh secara parsial variabel kompetensi perangkat desa $\left(\mathrm{X}_{1}\right)$, variabel sistem pengendalian internal $\left(\mathrm{X}_{2}\right)$, variabel kepatuhan pajak bendaharawan desa $\left(\mathrm{X}_{3}\right)$ dan variabel partisipasi masyarakat $\left(\mathrm{X}_{4}\right)$ terhadap variabel akuntabilitas pengeloaan alokasi dana desa (Y) di Desa Tegalweru Kabupaten Malang. Adapun besarnya nilai masing-masing pengaruh dari variabel bebas terhadap variabel terikat dapat diketahui pada tabel berikut:

Tabel 4. Hasil Uji t

\begin{tabular}{cccc}
\hline Variabel & t hitung & $\mathrm{t}$ tabel & Sig t \\
\hline$\left(\mathrm{X}_{1}\right)$ & 3,188 & & 0,002 \\
$\left(\mathrm{X}_{2}\right)$ & 3,546 & \multirow{2}{*}{1,980} & 0,000 \\
$\left(\mathrm{X}_{3}\right)$ & 6,016 & & 0,000 \\
$\left(\mathrm{X}_{4}\right)$ & 7,562 & & 0,000 \\
\hline
\end{tabular}

Sumber: Data primer (diolah), 2021

Hasil perhitungan uji t untuk mengetahui pengaruh dari masing-masing variabel yaitu: Variabel kompetensi perangkat desa $\left(\mathrm{X}_{1}\right)$ berpengaruh signifikan terhadap variabel akuntabilitas pengeloaan alokasi dana desa (Y) di Desa Tegalweru Kabupaten Malang karena nilai thitung = $3,188>t_{\text {tabel }}$ 1,980 dengan nilai signifikan sebesar 0,002 ( $\left.p<0,05\right)$, sehingga $\mathrm{H}_{1}$ diterima. Hal ini berarti semakin baik dukungan dari kompetensi perangkat desa akan meningkatkan akuntabilitas pengeloaan alokasi dana desa.

Variabel sistem pengendalian internal $\left(\mathrm{X}_{2}\right)$ berpengaruh signifikan terhadap variabel akuntabilitas pengeloaan alokasi dana desa (Y) di Desa Tegalweru Kabupaten Malang karena nilai $t_{\text {hitung }}=3,546>t_{\text {tabel }} 1,980$ dengan nilai signifikan sebesar $0,000(\mathrm{p}<0,05)$, sehingga $\mathrm{H}_{2}$ 
diterima. Hal ini berarti semakin baik dukungan dari sistem pengendalian internal akan meningkatkan akuntabilitas pengeloaan alokasi dana desa.

Variabel kepatuhan pajak bendaharawan desa $\left(\mathrm{X}_{3}\right)$ berpengaruh signifikan terhadap variabel akuntabilitas pengeloaan alokasi dana desa (Y) di Desa Tegalweru Kabupaten Malang karena nilai $\mathrm{t}_{\text {titung }}=6,016>\mathrm{t}_{\text {tabel }} 1,980$ dengan nilai signifikan sebesar $0,000(\mathrm{p}<0,05)$, sehingga $\mathrm{H}_{3}$ diterima. Hal ini berarti semakin baik dukungan dari kepatuhan pajak bendaharawan desa akan meningkatkan akuntabilitas pengeloaan alokasi dana desa.

Variabel partisipasi masyarakat $\left(\mathrm{X}_{4}\right)$ berpengaruh signifikan terhadap variabel akuntabilitas pengeloaan alokasi dana desa (Y) di Desa Tegalweru Kabupaten Malang karena nilai $t_{\text {hitung }}=7,562>t_{\text {tabel }}$ 1,980 dengan nilai signifikan sebesar $0,000(\mathrm{p}<0,05)$, sehingga $\mathrm{H}_{4}$ diterima. Hal ini berarti semakin baik dukungan dari partisipasi masyarakat akan meningkatkan akuntabilitas pengeloaan alokasi dana desa.

Koefisien determinasi $\left(\mathrm{R}^{2}\right)$ pada intinya mengukur seberapa jauh kemampuan model dalam menerangkan variasi variabel dependen. Hasil analisis didapakan nilai $r$ square sebesar 0,806 artinya kompetensi perangkat desa, sistem pengendalian internal, kepatuhan pajak bendaharawan desa dan partisipasi masyarakat memiliki kontribusi terhadap akuntabilitas pengeloaan alokasi dana desa di Desa Tegalweru Kabupaten sebesar 80,6\% dan sisanya sebesar 0,194 atau 19,4\% oleh variabel lain yang tidak diteliti seperti transparansi dan kinerja perangkat desa.

Hasil analisis yang telah disajikan membuktikan bahwa kompetensi perangkat desa berpengaruh signifikan terhadap akuntabilitas pengeloaan alokasi dana desa di Desa Tegalweru Kabupaten Malang dengan nilai $t_{\text {hitung }}=3,188$, nilai signifikan sebesar 0,002 dan nilai koefisien regresi sebesar 0,574 , sehingga $\mathrm{H}_{1}$ diterima. Hal ini berarti semakin baik dukungan dari kompetensi perangkat desa akan meningkatkan akuntabilitas pengeloaan alokasi dana desa. Kompetensi perangkat desa yang berpengaruh terhadap akuntabilitas pengeloaan alokasi dana desa seperti mempunyai keterampilan menyusun laporan dan data, memiliki pengetahuan terkait kebijakan dan program pemerintahan desa, serta memiliki kemampuan untuk melaksanakan tugas dengan benar.

Hasil penelitian ini sesuai dengan penelitian Arifiyanto (2014) menjelaskan bahwa akuntabilitas pengeloaan alokasi dana desa didukung oleh faktor kompetensi perangkat desa dalam mengelola keuangan desa. Kompetensi mengacu pada pengetahuan, keterampilan dan kempuan yang dapat ditunjukkan dengan menggunakan strandar tertentu. Apabila rendahnya kompetensi sumber daya manusia aparat pemerintah desa merupakan faktor penghambat terwujudnya akuntabilitas pengelolaan keuangan desa. Kopetensi merupakan kemampuan perangkat desa dalam menjalankan tugasnya dengan benar sehingga mendukung akuntabilitas pengeloaan alokasi dana desa.

Hasil analisis yang telah disajikan membuktikan bahwa sistem pengendalian internal berpengaruh signifikan terhadap akuntabilitas pengeloaan alokasi dana desa di Desa Tegalweru Kabupaten Malang dengan nilai $t_{\text {hitung }}=3,546$, nilai signifikan sebesar 0,000 dan nilai koefisien regresi sebesar 0,617 , sehingga $\mathrm{H}_{2}$ diterima. Hal ini berarti semakin baik dukungan dari sistem pengendalian internal akan meningkatkan akuntabilitas pengeloaan alokasi dana desa. Sistem pengendalian internal yang berpengaruh terhadap akuntabilitas pengeloaan alokasi dana desa seperti pegawai saling bekerja sama untuk mendorong efektivitas dan efisiensi pekerjaan dan pegawai teliti dalam melakukan pekerjaan yang dilakukan.

Hasil penelitian ini sesuai dengan penelitian Thomas (2013) menjelaskan bahwa sistem pengendalian internal berpengaruh terhadap akuntabilitas pengeloaan alokasi dana desa, semakin baik pengendalian internal maka akan mempengaruhi kinerja pegawai desa. Sistem pengendalian internal meliputi truktur organisasi, metode dan ukuran-ukuran yang di koordinasikan untuk menjaga aset organisasi, mengecek ketelitian dan keandalan data akuntansi, mendorong efisiensi dan mendorong dipatuhinya kebijakan manajemen. Sistem pengendalian intern berfungsi sebagai tindakan dan kegiatan yang dilakukan oleh manajemen dan seluruh pegawai desa agar tujuan 
organisasi dapat dicapai melalui pekerjaan yang dilakukan dan melakukan pelaporan keuangan dengan baik. Hasil penelitian ini membuktikan bahwa pemanfaatan sistem pengendalian internal dapat meningkatkan akuntabilitas pengelolaan keuangan desa.

Hasil analisis yang telah disajikan membuktikan bahwa kepatuhan pajak bendaharawan desa berpengaruh signifikan terhadap akuntabilitas pengeloaan alokasi dana desa di Desa Tegalweru Kabupaten Malang dengan nilai thitung $=6,016$, nilai signifikan sebesar 0,000 dan koefisien regresi sebesar 0,716 , sehingga $\mathrm{H}_{3}$ diterima. Hal ini berarti semakin baik dukungan dari kepatuhan pajak bendaharawan desa akan meningkatkan akuntabilitas pengeloaan alokasi dana desa. Kepatuhan pajak bendaharawan desa yang berpengaruh terhadap akuntabilitas pengeloaan alokasi dana desa seperti bendaharawan desa secara profesional dalam menghitung pajak desa dan profesional dalam mengelola dana desa.

Hasil penelitian ini sesuai dengan penelitian Setiawan dkk., (2017) menjelaskan bahwa kepatuhan pajak bendaharawan desa mampu meningkatkan akuntabilitas pengeloaan alokasi dana desa, dimana semakin efisien pengelolaan pajak desa mampu meningkatkan akuntabilitas pengeloaan alokasi dana desa. Kepatuhan pajak bendaharawan desa didefinisikan sebagai memasukkan dan melaporkan data pada waktunya informasi yang diperlukan. Upaya dalam peningkatan penerimaan pajak mulai dari reformasi sistem administrasi perpajakan, peningkatan kepatuhan pajak hingga peningkatan kualitas layanan. Kepatuhan pajak bendaharawan desa merupakan kemampuan pegawai desa dalam mengelola pajak desa.

Hasil analisis yang telah disajikan membuktikan bahwa partisipasi masyarakat berpengaruh signifikan terhadap akuntabilitas pengeloaan alokasi dana desa di Desa Tegalweru Kabupaten Malang dengan nilai $t_{\text {hitung }}=7,562$, nilai signifikan sebesar 0,000 dan nilai koefisien regresi sebesar 0,794 , sehingga $\mathrm{H}_{4}$ diterima. Hal ini berarti semakin baik dukungan dari partisipasi masyarakat akan meningkatkan akuntabilitas pengeloaan alokasi dana desa. Partisipasi masyarakat yang berpengaruh terhadap akuntabilitas pengeloaan alokasi dana desa seperti masyarakat selalu mengusulkan rencana anggaran pembangunan desa dan terlibat mengawasi alokasi dana desa.

Hasil penelitian ini sesuai dengan penelitian Perdana (2018) menjelaskan bahwa partisipasi masyarakat dan pemanfaatan teknologi informasi berpengaruh positif terhadap akuntabilitas pengelolaan dana desa, dimana adanya partisipasi masyarakat akan meningkatkan akuntabilitas pengelolaan dana desa. Partisipasi masyarakat sebagai keterlibatan masyarakat dalam memberi pendapat terkait pengelolaan dana desa. Partisipasi masyarakat berperan penting dalam mengontrol pengelolaan dana desa sehingga bisa dikelola oleh perangkat desa dengan baik. Akuntabilitas pengelolaan dana desa menyangkut kemampuan pemerintah desa mempertanggung jawabkan kegiatan dalam pengelolaan dana desa untuk mendukung pembangunan desa yang berkembang.

\section{KESIMPULAN}

Hasil penelitian membuktikan bahwa kompetensi perangkat desa berpengaruh signifikan terhadap akuntabilitas pengeloaan alokasi dana desa di Desa Tegalweru Kabupaten Malang, artinya semakin baik dukungan dari kompetensi perangkat desa akan meningkatkan akuntabilitas pengeloaan alokasi dana desa. Kompetensi perangkat desa yang berpengaruh terhadap akuntabilitas pengeloaan alokasi dana desa seperti mempunyai keterampilan menyusun laporan dan data, memiliki pengetahuan terkait kebijakan dan program pemerintahan desa, serta memiliki kemampuan untuk melaksanakan tugas dengan benar. Sistem pengendalian internal berpengaruh signifikan terhadap akuntabilitas pengeloaan alokasi dana desa, artinya semakin baik dukungan dari sistem pengendalian internal akan meningkatkan akuntabilitas pengeloaan alokasi dana desa. Sistem pengendalian internal yang berpengaruh terhadap akuntabilitas pengeloaan alokasi dana desa seperti pegawai saling bekerja sama untuk mendorong efektivitas 
dan efisiensi pekerjaan dan pegawai teliti dalam melakukan pekerjaan yang dilakukan. Kepatuhan pajak bendaharawan desa berpengaruh signifikan terhadap akuntabilitas pengeloaan alokasi dana desa, artinya semakin baik dukungan dari kepatuhan pajak bendaharawan desa akan meningkatkan akuntabilitas pengeloaan alokasi dana desa. Kepatuhan pajak bendaharawan desa yang berpengaruh terhadap akuntabilitas pengeloaan alokasi dana desa seperti bendaharawan desa secara profesional dalam menghitung pajak desa dan profesional dalam mengelola dana desa. Partisipasi masyarakat berpengaruh signifikan terhadap akuntabilitas pengeloaan alokasi dana desa, artinya semakin baik dukungan dari partisipasi masyarakat akan meningkatkan akuntabilitas pengeloaan alokasi dana desa. Partisipasi masyarakat yang berpengaruh terhadap akuntabilitas pengeloaan alokasi dana desa seperti masyarakat selalu mengusulkan rencana anggaran pembangunan desa dan terlibat mengawasi alokasi dana desa.

\section{DAFTAR PUSTAKA}

Ahmad Farouk,M Yasin dkk, 2015, Anotasi Undang - Undang No.6 tahun 2014 tentang Desa, PATTIRO, Jakarta

Djalil, Rizal.2014. Akuntabilitas Keuangan Daerah Implementasi Pasca Reformasi.Jakarta:PT Semesta Rakyat Merdeka.

Gayatri, G., Latrini, M. Y., \& Widhiyani, N. L. S. (2017). Transparansi dan Akuntabilitas Pengelolaan Keuangan Dana Desa untuk Mendorong Kemandirian Masyarakat Pedesaan. $\begin{array}{lllll}\text { Jurnal Ekonomi } & \text { Kuantitatif } & \text { Terapan, } & 175-\end{array}$ https://doi.org/10.24843/jekt.2017.v10.i02.p07

Gayatri, \& Latrini, M. Y. (2018). Efektivitas Penerapan SISKEUDES dan Kualitas Laporan Keuangan Dana Desa. Jurnal Imiah Akuntansi Dan Bisnis, 13(2), 113- 122.

Ghozali, Imam. 2011. "Aplikasi Analisis Multivariate Dengan Program SPSS". Semarang: Badan Penerbit Universitas Diponegoro.

Ghozali, Imam. 2013. Aplikasi Analisis Multivatiate Dengan Program IBM SPSS 20. Edisi 6. Semarang : Badan Penerbit Universitas Diponegoro.

Ghozali, Imam. (2016). Aplikasi Analisis Multivariete dengan Program IBM SPSS 21. Semarang: Badan Penerbit Universitas Diponegoro.

Mardiasmo. 2009. Akuntansi Sektor Publik. Yogyakarta: Andi Yogyakarta.

Mardiasmo. 2002."Otonomi dan Manajemen Keuangan Daerah dan Pengelolaan Dana dengan Prinsip Value for Money, Edisi ke 5 Tahun 2002".

Mada, Syarifudin, Linjte Kelangi dan Hendrik Gamaliel. 2017. Pengaruh Kompetensi Aparat Pengelola Dana Desa, Komitmen Organisasi Pemerintah Desa, Dan Partisipasi Masyarakat Terhadap Akuntabilitas Pengelolaan Dana Desa Di Kabupaten Gorontalo.

Munti, Finta dan Heru Pahlevi. 2017. Determinan Kinerja Pengelolaan Keuangan Desa: Studi pada Kecamatan Gandapura Kabupaten Bireuen Aceh. Jurnal Akuntansi dan Investasi, Vol. 18 No. 2 Hal: 172-182.

Pemerintah Republik Indonesia. 2014. Undang-Undang Nomor 6 Tahun 2014 tentang Desa. Jakarta: Indonesia.

Peraturan Menteri Dalam Negeri Nomor 113 Tahun 2014 tentang Pengelolaan Keuangan Desa. (2014).

Peraturan Menteri Dalam Negeri Republik Indonesia Nomor 43 Tahun 2014 tentang prioritas penggunaan dana desa.

Peraturan Pemerintah Nomor 72 Tahun 2005 tentang Desa

Peraturan Pemerintah Republik Indonesia Nomor 60 Tahun 2014 tentang Dana Desa Bersumber dari Anggaran Pendapatan dan Belanja Negara.

Peraturan Menteri Desa, Pembangunan Daerah Tertinggal dan Transmigrasi Republik Indonesia Nomor 22 Tahun 201 Tentang Penetapan Prioritas Penggunaan Dana Desa Tahun 2017. 
Setiana, Novindra Dwi dan Nur Laila Yuliani. 2017. Pengaruh Pemahaman Dan Peran Perangkat Desa Terhadap Akuntabilitas Pengelolaan Dana Desa. The 6th University Research Colloquium 2017Universitas Muhammadiyah Magelang.

Setiawan,Made Wiradarma, A. Tungga Atmaja, dan N.L.G. Erni Sulindawati. 2017. Analisis Transparansi Dan Akuntabilitas Pelaporan Alokasi Dana Desa (Studi Kasus Desa Bengkel, Kec. Busungbiu, Kab. Buleleng). EJournal S1 Ak Universitas Pendidikan Ganesha Jurusan Akuntansi Program S1, Vol: 7 No:1

Subroto, Agus. 2009. Akuntabilitas Pengelolaan Dana Desa (Studi Kasus Pengelolaan Alokasi Dana Desa di Desa-desa dalam wilayah Kecamatan Tlogomulyo Kabupaten Temanggung Tahun 2008). Tesis. Semarang: Pasca Sarjana Universitas Diponegoro.

Susanti, I., Syairozi, M. I., \& Lukman, H. Y. W. (2021). Analisis Sistem Manajemen Dalam Pengelolaan Bumdes Di Desa Bluluk. Jurnal Sains Sosio Humaniora, 5(2), 701-710.

Sujarweni, V. Wiratna. 2015. Akuntansi Biaya. Yogyakarta: Pustaka Baru Press.

Sujarweni, V. Wiratna. 2015. Akuntansi Manajemen. Yogyakarta: Pustaka Baru Press.

Sujarweni, V. Wiratna. 2015. Statistik untuk Bisnis dan Ekonomi. Yogyakarta: Pustaka Baru Press.

Sujarweni, Wiratna. (2015). Akuntansi Desa-PandunTata Kelola Keuangan Desa. Yogyakarta: Pustaka Baru Press.

Sujarweni, Wiratna. 2012. StatistikaUntuk Penelitian. Yogyakarta: Graha ilmu

Sugiyono .(2016).Metode Penelitian Kuantitatif, Kualiatif, Dan Kombinasi (mixed methodes). Bandung; Alfabeta.

Syairozi, M. I. (2017). Aplikasi Akad Musyarakah pada Pembiayaan Unit Usaha Syariah PT Bank Rakyat Indonesia (PERSERO), Tbk. PROCEEDINft, 111.

Widjaja. 2001. Pemerintahan Desa/Marga, Berdasarkan UU No. 22 Tahun 1999 Tentang Pemerintahan Daerah. Jakarta: Raja Grafindo Persada. Widjaja, HAW. 2003. Pemerintahan Desa dan Administrasi. Jakarta: Rajawali Press. 